\title{
Mantle flow beneath Arabia offset from the opening Red Sea
}

\author{
Sung-Joon Chang, ${ }^{1}$ Miguel Merino, ${ }^{1}$ Suzan Van der Lee, ${ }^{1}$ Seth Stein, ${ }^{1}$ and Carol A. Stein ${ }^{2}$ \\ Received 13 October 2010; revised 9 December 2010; accepted 24 December 2010; published 16 February 2011.
}

[1] Continental rifting involves a poorly understood sequence of lithospheric stretching, volcanism, and mantle flow that evolves to seafloor spreading. We present new insight from inversion of seismic traveltimes and waveforms beneath Arabia and surroundings. Low velocities occur beneath the southern Red Sea and Gulf of Aden, consistent with active spreading. However, hot material extends not below the northern Red Sea, but is offset eastward beneath Arabia, showing mantle flow from the Afar hotspot. The location of this channel beneath volcanic rocks erupted since rifting began 30 million years ago indicates that flow moves with Arabia. We propose that the absence of seafloor spreading in the northern Red Sea reflects the offset flow. This geometry may evolve to spreading in the Northern Red Sea, rifting of Arabia, or both. This situation has aspects of both active and passive rifting, showing that both can occur before coalescing to seafloor spreading. Citation: Chang, S.-J., M. Merino, S. Van der Lee, S. Stein, and C. A. Stein (2011), Mantle flow beneath Arabia offset from the opening Red Sea, Geophys. Res. Lett., 38, L04301, doi:10.1029/2010GL045852.

\section{Introduction}

[2] The primary question about continental rifting is the chicken-and-egg issue of how mantle flow and lithospheric extension are related. The initiation of rifting can be described by end member models of either active rifting initiated by hot mantle material upwelling below a continent and weakening it, or passive rifting initiated by stresses within the lithosphere due in most cases to plate motions that thin the continent, causing mantle upwelling and volcanism [Sengör and Burke, 1978]. The combined effects of these processes, whose sequence and relative roles are unclear and likely vary between rifts, sometimes cause rifting to progress from stretching and faulting the continental lithosphere to active seafloor spreading.

[3] The relative roles of active and passive rifting are hard to resolve because they are ongoing today in only a few places. The best examples are associated with the rifting of Arabia from Africa (Figure 1). During the past $30 \mathrm{Ma}$, Arabia's motion away from Nubia (West Africa) and Somalia (East Africa) formed the Red Sea and Gulf of Aden [Le Pichon and Gaulier, 1988; Bosworth et al., 2005; Garfunkel and Beyth, 2006]. The spreading centers in these young ocean basins, together with the East African rift, are the arms of the Afar triple junction. This system appears to have evolved as a result of a major episode of magmatism and

\footnotetext{
${ }^{1}$ Department of Earth and Planetary Sciences, Northwestern University, Evanston, Illinois, USA.

${ }^{2}$ Department of Earth and Environmental Sciences, University of Illinois at Chicago, Chicago, Illinois, USA.

Copyright 2011 by the American Geophysical Union. 0094-8276/11/2010GL045852
}

uplift beginning about 30-40 Ma that is interpreted as the beginning of the Afar hotspot [Ebinger and Sleep, 1998; Courtillot et al., 1999] and forces due to the subduction of the Tethyan ocean lithosphere beneath Eurasia that is presently closing the Persian Gulf [McQuarrie et al., 2003].

[4] Two arms present a consistent picture between lithospheric extension, volcanism, and mantle flow. The Ethiopia arm is undergoing continental extension and volcanism, underlain by low velocity - presumably hot - material [Debayle et al., 2001]. Shear-wave splitting data [Gashawbeza et al., 2004] show the fast direction parallel to the rift, consistent with mantle flow along it. The Gulf of Aden arm shows seafloor spreading, recorded by the magnetic anomalies in crust formed at the spreading center, along its entire length [Cochran, 1981].

[5] However, the Red Sea arm is more complicated. Seafloor magnetic anomalies and normal faulting earthquakes typically associated with slow spreading ridges occur almost exclusively south of $21^{\circ} \mathrm{N}$ where a deep axial trough is present [Chu and Gordon, 1998; Cochran and Karner, 2007]. To the north, only a few isolated anomalies are identified, and the sea is floored by rotated fault blocks. Thus the northern area is interpreted as continental crust being stretched and faulted with only minor volcanic activity, whereas the southern area has evolved to the point that new lithosphere is being produced at a spreading axis. This situation has been viewed as transient until the extension in the northern area evolves into seafloor spreading. This model is consistent with magnetic and GPS data showing that the rate of opening decreases from about $18 \mathrm{~mm} / \mathrm{yr}$ at $16^{\circ} \mathrm{N}$ to about $10 \mathrm{~mm} / \mathrm{yr}$ at $26^{\circ} \mathrm{N}$ [Chu and Gordon, 1998; ArRajehi et al., 2010].

\section{Tomographic Image}

[6] We investigate this transition using a seismic tomographic image of velocity structure beneath Arabia and surroundings derived by joint inversion of a compilation of data. The compilation, described in the auxiliary material, includes global and regional data sets of arrival times, body wave waveforms, regional multimode $\mathrm{S}$ and surface wave trains, surface wave group velocities, and constraints on Moho depth from active source seismic studies, gravity surveys, global geological and geophysical interpretations, and receiver functions.

[7] The results are shown in cross sections across the Red Sea and Gulf of Aden (Figure 2). Low velocities indicating hot mantle are visible below $50 \mathrm{~km}$ beneath spreading axes in the Gulf of Aden (profiles G-g, H-h, and I-i) and southern Red Sea (profiles D-d, E-e, and F-f). However, below the northern Red Sea the slowest material is offset to the east, below Arabia (profiles A-a, B-b, and C-c).

\footnotetext{
${ }^{1}$ Auxiliary materials are available in the HTML. doi:10.1029/ 2010GL045852.
} 


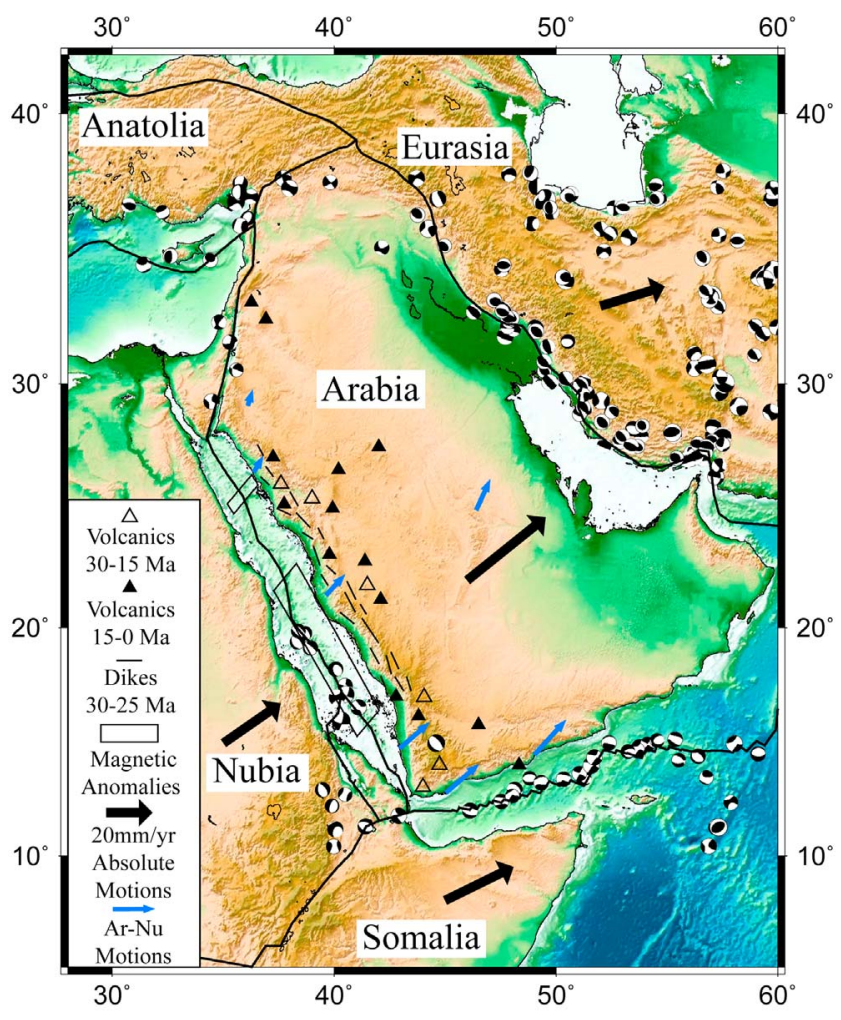

Figure 1. Tectonics of the Nubia-Arabia-Somalia threeplate system showing relative and absolute plate motions [ArRajehi et al., 2010], locations of volcanism and dikes [Dixon et al., 1989; Camp and Roobol, 1992], and selected focal mechanisms from CMT catalog.

[8] This difference is illustrated by an image at $150 \mathrm{~km}$ (Figure 3). Low velocities occur beneath the Gulf of Aden and southern Red Sea. However, the lowest velocity material beneath the southern Red Sea does not extend northwestward below the Red Sea, but instead forms a channel trending northward beneath Arabia. Shear wave splitting directions show northward flow parallel to the channel rather than to the Red Sea [Hansen et al., 2006; Sebai et al., 2006].

[9] The upper-mantle low-velocity region has been imaged, first as a broad zone and then as a channel, in successive earlier regional studies with progressively increasing resolution [Hadiouche and Zurn, 1992; Debayle et al., 2001; Pasyanos and Nyblade, 2007; Sicilia et al., 2008]. Our dataset combines much of the data used in these studies in a joint inversion. The resulting improved resolution shows that the low velocity channel is shallow (extending from 100 $300 \mathrm{~km}$ ), narrow (less than $500 \mathrm{~km}$ wide), and displaced eastward rather than extending under the northern Red Sea. This geometry supports the earlier interpretation of northward flow in the mid upper-mantle from the Afar hotspot [Park et al., 2008], but shows that the channel is offset from the northern Red Sea and hence does not represent mantle flow along the Red Sea. Resolution tests in the auxiliary material show that the low-velocity region is a narrow channel rather than a broad regional anomaly, and that this channel occurs below Arabia rather than the northern Red Sea.

\section{Tectonic Interpretation}

[10] The geometry of the low velocity anomaly and the shear wave splitting directions jointly favor their being due to mantle flow, as observed elsewhere [Russo et al., 2010]. However, this geometry differs from cases in which the splitting directions can be interpreted as mantle flow driven by absolute plate motions [Silver, 1996], because Arabia's NW-SE absolute motion does not match the N-S flow and splitting directions. The narrowness of the velocity anomaly and its depth extent preclude its being due to lithospheric thickness [Rychert and Shearer, 2009].

[11] The new data also suggest how the flow may have evolved. Prior to the availability of tomographic data, the presence of upwelling mantle beneath Arabia was proposed based on the presence of elevated topography and 20-30 Ma volcanism and dike swarms trending parallel to the Red Sea but up to several hundred $\mathrm{km}$ eastward [Dixon et al., 1989]. Because little uplift and volcanism occur on the west side of the Red Sea, the asymmetric volcanism and uplift were hypothesized to reflect the initial location of upwelling that caused the Red Sea rifting as Arabia migrated northeastward over the upwelling which was assumed to be fixed in the mantle.

[12] However, the tomographic data show that the hot mantle flow is not beneath the Red Sea. Instead, it occurs beneath the loci of two distinct phases of volcanism in western Arabia. As previously observed [Camp and Roobol, 1992], the older (pre-15 Ma) northwest-trending volcanism and younger north-trending volcanism that continues to the present, overlap with different trends. Thus we hypothesize that the flow from the fixed or slow-moving hotspot forms a channel that has lengthened with time and been deflected by Arabia's northeastward absolute motion, such that it remains below Arabia but rotated to a more north-south trend consistent with that of the younger volcanics. Figure 4 shows such a scenario, in which present plate motions are used throughout because their detailed history is not well known. The deflection is favored by the fact that Arabia's absolute motion is almost perpendicular to the Red Sea. Analogous deflection of upwelling mantle by absolute plate motion has been proposed for the Eifel hotspot [Walker et al., 2007].

[13] This model is schematic in several ways. The channel geometry is reasonably but not perfectly resolved. A similar direction of anisotropy is observed east of the channel, where lithosphere is thicker [Stern and Johnson, 2010], consistent with the view that anisotropy can arise from both mantle flow and lithospheric structure [Hansen et al., 2006]. Not all volcanism is directly above the channel, presumably because the locations of volcanism also reflect structures in the lithosphere or due to ongoing opening of the Red Sea. Most intriguingly, the volcanism occurred in pulses rather than continuously. However, the model offers a general explanation for the persistence of volcanism with changing trend above the channel's current location. It is consistent with geochemical data [Camp and Roobol, 1992; Krienitz et al., 2009] interpreted as showing that the Arabian volcanics 


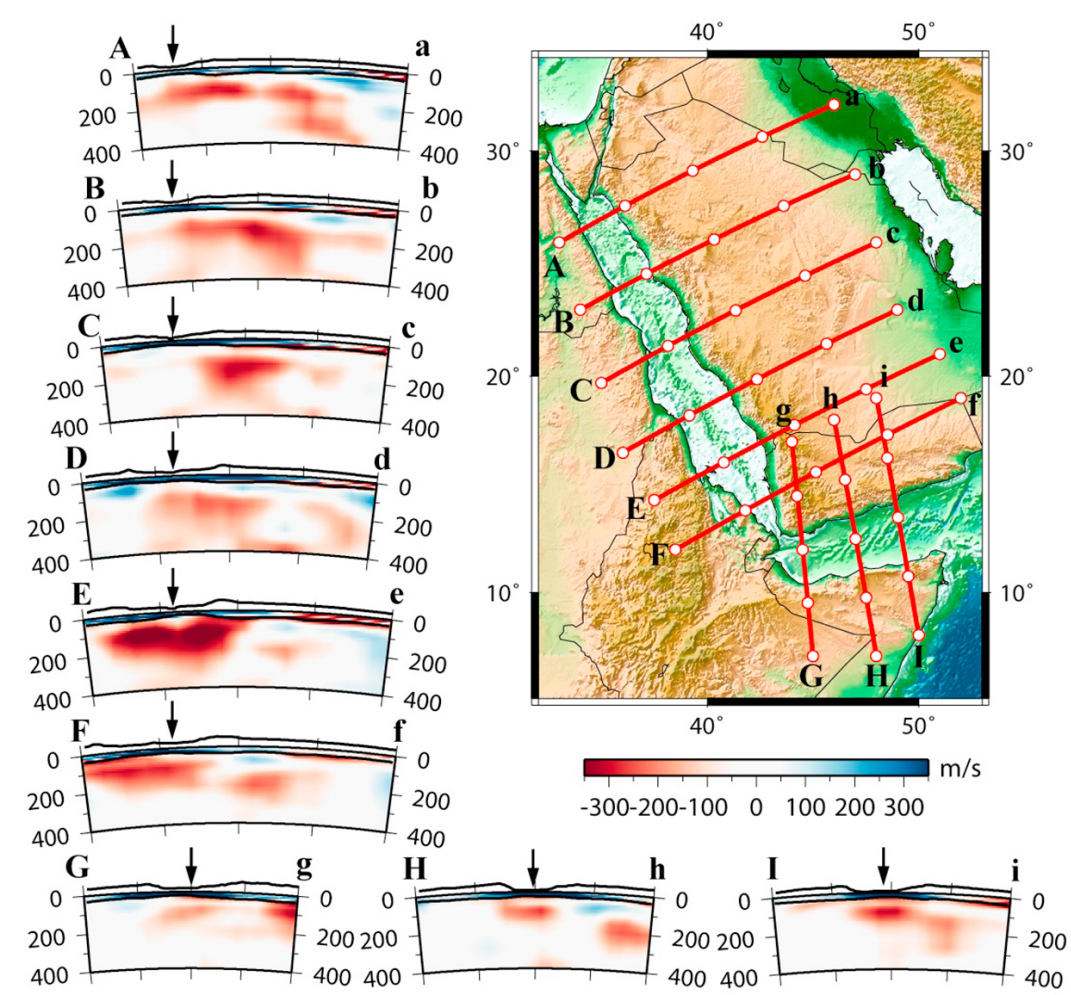

Figure 2. Shear wave velocity cross-sections across the Red Sea and Gulf of Aden. Seafloor and surface topography are shown by black solid lines with tenfold vertical exaggeration. Moho depth is also shown. Black arrow indicates location of the ridge on each cross section. White circles on the map correspond to ticks in the cross sections.

reflect melting that progressed northward and involved a plume source.

[14] This geometry may have evolved as flow from the hotspot was channeled by the pre-rifting structure of the base of the lithosphere [Ebinger and Sleep, 1998] and may still be affected by lithospheric structure. In particular, Cenozoic volcanic activity is absent in the Afif Terrane that contains some of the oldest crust in the Arabian Shield, of Paleoproterozoic age, but present to the west [Stoeser and Frost, 2006]. Similarly, the locus of rifting may have been controlled by preexisting weakness in the continental lithosphere [Dixon et al., 1989; Cloetingh et al., 1995].

[15] This situation shows aspects of both active and passive rifting models, and could remain as is or evolve in either direction (Figure 4). There is no reason to believe that active sea floor spreading will begin soon in the northern Red Sea, because the hot mantle flow remains to the east. The present regime of extension in the north seems stable, as also suggested by the basement fault geometry [Cochran and Karner, 2007]. It could eventually evolve into sea floor spreading, in which case the mantle flow should be deflected to the northern Red Sea, as observed below the Gulf of Aden. At present this seems not to be occurring, given the shear-wave splitting data. Alternatively, active rifting could evolve in Arabia above the channel, given that some extension occurs along the active volcanic trend [Camp and Roobol, 1992; Pallister et al., 2010]. Ultimately, the northern Red Sea rift could be abandoned. This "rerifting" situation would be similar those observed in the North Atlantic, where volcanism associated with hotspots produced renewed continental rifting that eventually developed into new seafloor spreading axes [Skogseid et al., 2000; Müller et al., 2001].

[16] Arabia and its surroundings thus illustrate how many complexities of the rifting process observed in the geological record [Corti et al., 2003; Huismans and Beaumont,

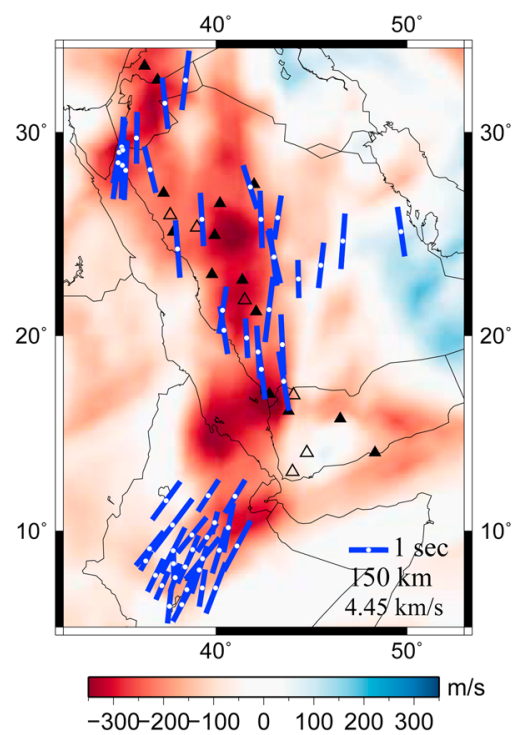

Figure 3. Shear wave velocity map at $150 \mathrm{~km}$ depth, showing perturbations relative to reference velocity. Shear wave splitting data are from Gashawbeza et al. [2004] and Hansen et al. [2006]. 


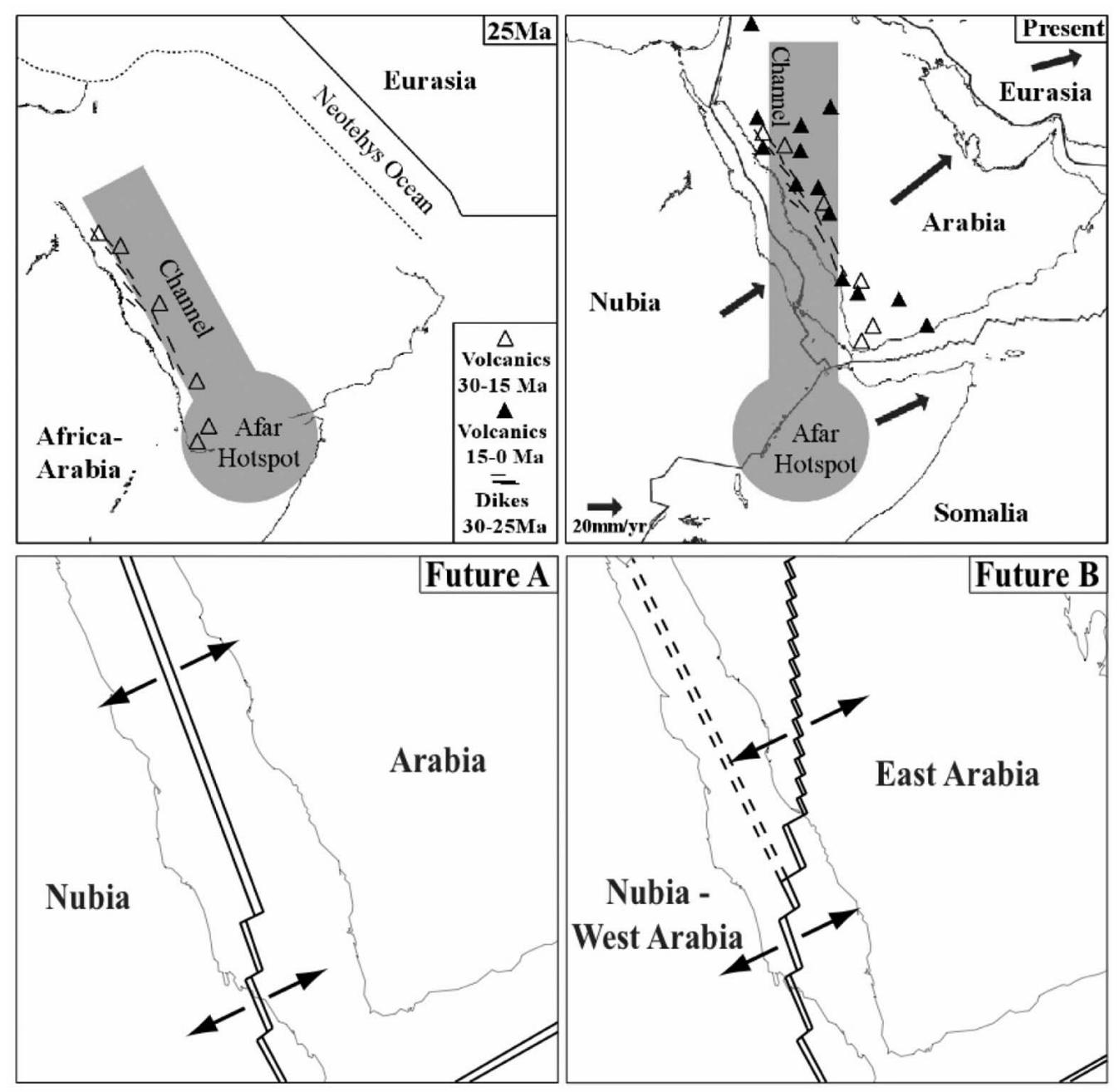

Figure 4. (top) Schematic model for the evolution of the low velocity channel, assuming flow from a fixed hotspot has been deflected by Arabia's northeastward absolute motion. (bottom) Possible future geometries in which (left) extension in the northern Red Sea develops into seafloor spreading or ceases as rifting develops within Arabia along the low velocity channel and (right) progresses to seafloor spreading.

2003] can arise. The order, timing, magnitude, and locations of volcanism and extension have varied during rifting, as shown by the fact that the East Africa rift has considerable volcanism and little extension, whereas the Gulf of Aden has less volcanism but more extension. The fact that in the Red Sea and Arabia a situation with aspects of both active and passive rifting occurs and seems stable for some time illustrates that lithospheric extension and mantle flow can act somewhat independently in different places for a long time before coalescing to seafloor spreading.

[17] Acknowledgments. We thank S. McClusky for providing GPS results and H. Bedle, M. Benoit, E. Engdahl, M. Flanagan, F. Marone, E. Matzel, W. Mooney, A. Nyblade, Y. Park, M. Pasyanos, and C. Schmid for providing seismological data and results. We thank S. Cloetingh and Z. Garfunkel for helpful comments.

\section{References}

ArRajehi, A., et al. (2010), Geodetic constraints on present-day motion of the Arabian plate, Tectonics, 29, TC3011, doi:10.1029/2009TC002482.
Bosworth, W., J. Huchon, and K. McClay (2005), The Red Sea and Gulf of Aden basins, J. Afr. Earth Sci., 43, 334-378, doi:10.1016/j.jafrearsci. 2005.07.020.

Camp, E., and M. J. Roobol (1992), Upwelling asthenosphere beneath western Arabia and its regional implications, J. Geophys. Res., 97, 15,255-15,271, doi:10.1029/92JB00943.

Chu, D., and R. G. Gordon (1998), Current plate motions across the Red Sea, Geophys. J. Int., 135, 313-328, doi:10.1046/j.1365-246X. 1998.00658.x.

Cloetingh, S., et al. (1995), Role of pre-rift rheology in kinematics of extensional basin formation, Mar. Pet. Geol., 12, 793-807, doi:10.1016/02648172(95) $98848-\mathrm{Y}$.

Cochran, J. R. (1981), The Gulf of Aden: Structure and evolution of a young ocean basin and continental margin, J. Geophys. Res., 86, 263-287, doi:10.1029/JB086iB01p00263.

Cochran, J. R., and G. D. Karner (2007), Constraints on the deformation and rupturing of continental lithosphere of the Red Sea, in Imaging, Mapping and Modeling Continental Lithosphere Extension and Breakup, edited by G. D. Karner et al., Geol. Soc. Publ., 282, 265-289.

Corti, G., J. Van Wijk, M. Bonini, D. Sokoutis, S. Cloetingh, F. Innocenti, and P. Manetti (2003), Transition from continental break-up to punctiform seafloor spreading, Geophys. Res. Lett., 30(12), 1604, doi:10.1029/ 2003GL017374

Courtillot, V., et al. (1999), On causal links between flood basalts and continental breakup, Earth Planet. Sci. Lett., 166, 177-195, doi:10.1016/ S0012-821X(98)00282-9. 
Debayle, E., J.-J. Leveque, and M. Cara (2001), Seismic evidence for a deeply rooted low-velocity anomaly in the upper mantle beneath the northeastern Afro/Arabian continent, Earth Planet. Sci. Lett., 193, 423-436, doi:10.1016/S0012-821X(01)00509-X.

Dixon, T. H., E. R. Ivins, and B. J. Franklin (1989), Topographic and volcanic asymmetry around the Red Sea: Constraints on rift models, Tectonics, 8, 1193-1216, doi:10.1029/TC008i006p01193.

Ebinger, C. J., and N. H. Sleep (1998), Cenozoic magmatism throughout East Africa resulting from impact of a single plume, Nature, 395 788-791, doi:10.1038/27417.

Garfunkel, Z., and M. Beyth (2006), Constraints on the structural development of Afar imposed by the kinematics of the major surrounding plates, in The Afar Volcanic Province, edited by G. Yirgu et al., Geol. Soc. Spec. Publ., 259, 23-42.

Gashawbeza, E. M., S. L. Klemperer, A. A. Nyblade, K. T. Walker, and K. M. Keranen (2004), Shear-wave splitting in Ethiopia, Geophys. Res. Lett., 31, L18602, doi:10.1029/2004GL020471.

Hadiouche, O., and W. Zurn (1992), Structure of the crust and upper mantle beneath the Afro-Arabian region from surface wave dispersion, Tectonophysics, 209, 179-196, doi:10.1016/0040-1951(92)90022-X.

Hansen, S., et al. (2006), Combined plate motion and density-driven flow in the asthenosphere beneath Saudi Arabia, Geology, 34, 869-872, doi:10.1130/G22713.1.

Huismans, R. S., and C. Beaumont (2003), Symmetric and asymmetric lithospheric extension: Relative effects of frictional-plastic and viscous strain softening, J. Geophys. Res., 108(B10), 2496, doi:10.1029/ 2002JB002026.

Krienitz, M.-S., K. M. Haase, K. Mezger, P. van den Bogaard, V. Thiemann, and M. A. Shaikh-Mashail (2009), Tectonic events, continental intraplate volcanism, and mantle plume activity in northern Arabia: Constraints from geochemistry and Ar-Ar dating of Syrian lavas, Geochem. Geophys. Geosyst., 10, Q04008, doi:10.1029/2008GC002254.

Le Pichon, X., and J. M. Gaulier (1988), The rotation of Arabia and the Levant fault system, Tectonophysics, 153, 271-294, doi:10.1016/00401951(88)90020-0

McQuarrie, N., J. M. Stock, C. Verdel, and B. P. Wernicke (2003), Cenozoic evolution of Neotethys and implications for the causes of plate motions, Geophys. Res. Lett., 30(20), 2036, doi:10.1029/2003GL017992.

Müller, R. D., C. Gaina, W. R. Roest, and D. L. Hansen (2001), A recipe for microcontinent formation, Geology, 29(3), 203-206, doi:10.1130/ 0091-7613(2001)029<0203:ARFMF $>2.0 . \mathrm{CO} ; 2$.

Pallister, J., et al. (2010), Broad accommodation of rift-related extension recorded by dyke intrusion in Saudi Arabia, Nat. Geosci., 3, 705-712, doi:10.1038/ngeo 966 .
Park, Y., A. A. Nyblade, A. J. Rodgers, and A. Al-Amri (2008), S wave velocity structure of the Arabian Shield upper mantle from Rayleigh wave tomography, Geochem. Geophys. Geosyst., 9, Q07020, doi:10.1029/2007GC001895.

Pasyanos, M. E., and A. A. Nyblade (2007), A top to bottom lithospheric study of Africa and Arabia, Tectonophysics, 444, 27-44, doi:10.1016/j. tecto.2007.07.008.

Russo, R., et al. (2010), Subduction of the Chile Ridge: Upper mantle structure and flow, GSA Today, 20, 4-10, doi:10.1130/GSATG61A.1.

Rychert, C. A., and P. M. Shearer (2009), A global view of the lithosphereasthenosphere boundary, Science, 324, 495-498, doi:10.1126/science. 1169754 .

Sebai, A., et al. (2006), Anisotropic structure of the African upper mantle from Rayleigh and Love wave tomography, Phys. Earth Planet. Inter., 155, 48-62, doi:10.1016/j.pepi.2005.09.009.

Sengör, A. M. C., and K. Burke (1978), Relative timing of rifting and volcanism on Earth and its tectonic implications, Geophys. Res. Lett., 5 , 419-421, doi:10.1029/GL005i006p00419.

Sicilia, D., et al. (2008), Upper mantle structure of shear-waves velocities and stratification of anisotropy in the Afar hotspot region, Tectonophysics, 462, 164-177, doi:10.1016/j.tecto.2008.02.016.

Silver, P. (1996), Seismic anisotropy beneath the continents, Annu. Rev Earth Planet. Sci., 24, 385-432, doi:10.1146/annurev.earth.24.1.385.

Skogseid, J., et al. (2000), NE Atlantic continental rifting and volcanic margin formation, in Dynamics of the Norwegian Margin, edited by A. Nottvedt, Geol. Soc. Spec. Publ., 167, 295-326.

Stern, R. J., and P. Johnson (2010), Continental lithosphere of the Arabian plate: A geologic, petrologic, and geophysical synthesis, Earth Sci. Rev., 101, 29-67, doi:10.1016/j.earscirev.2010.01.002.

Stoeser, D. B., and C. D. Frost (2006), Nd, Pb, Sr, and O isotopic characterization of the Saudi Arabian Shield terranes, Chem. Geol., 226, 163-188, doi:10.1016/j.chemgeo.2005.09.019.

Walker, K. T., et al. (2007), Seismic anisotropy in the asthenosphere beneath the Eifel region, western Germany, in Mantle Plumes, edited by J. Ritter and U. Christensen, pp. 439-464, Springer, Berlin, doi:10.1007/978-3-540-68046-8_15.

S.-J. Chang, M. Merino, S. Stein, and S. Van der Lee, Department of Earth and Planetary Sciences, Northwestern University, Evanston, IL 60208, USA. (seth@earth.northwestern.edu)

C. A. Stein, Department of Earth and Environmental Sciences, University of Illinois at Chicago, 845 W. Taylor St., Chicago, IL 60607-7059, USA. 